\title{
Bisnafide Dimesylate
}

National Cancer Institute

\section{Source}

National Cancer Institute. Bisnafide Dimesylate. NCI Thesaurus. Code C73307.

The dimesylate salt form of bisnafide, a bis-naphthalimide compound with anticancer activity. Bisnafide selectively intercalates guanine-cytosine (GC) rich regions of DNA, thereby interfering with DNA replication machinery and activity of topoisomerase II. As a result, this agent causes potent cytotoxicity. 